\title{
RE-IMAGINING INDIGENEITY THROUGH PERFORMANCE: CREATIVE PATHWAYS TO URBAN ABORIGINALITY \& CULTURAL SURVIVAL
}

\author{
Angel Bright
}

\begin{abstract}
Due to the impacts of colonisation urban Indigenous Australians have been denied access to much of their cultural knowledge. It is their imagination, their own creativity in combining the knowledge that is available to them with other forms of cultural expression, which has helped provide the basis for an urban Aboriginality. By exploring the role of imagination and creativity in the process of cultural survival and the construction of identity, this paper examines contemporary experiences of Indigeneity among Aboriginal performers in Sydney, Australia. It provides an ethnographic account of the Woggan-ma-gule Morning Ceremony and discusses how a group of Indigenous performers are re-imagining Indigeneity and utilising creative action as a resource for challenging negative stereotypes of Aboriginality.
\end{abstract}

\section{INTRODUCTION}

Contemporary art forms are ways in which Aboriginal people can express their angers, frustrations, deep sorrows, hopes, awarenesses, and loves; their experience of living - or, as some put it, of 'surviving.' (Gaynor Macdonald 1991, 69).

Examining expressions of survival and identity through performance, this paper is based on ethnographic fieldwork conducted from 2007-2011 with the performers of the Indigenous Woggan-ma-gule Morning Ceremony, held on Australia Day in Sydney, New South Wales (NSw). Performed in the Royal Botanic Gardens at 8am, the Woggan-ma-gule ceremony is the first event on the national day programme. It is a free event and, despite its early start on a public holiday, is well attended by the public. Woggan-ma-gule is sponsored by the Australia Day Council of NSW (ADCNSW) ${ }^{1}$ but creatively led by Indigenous performers, the personal experiences of whom this paper is primarily 
concerned. The performers of Woggan-ma-gule range from elders to youth ${ }^{2}$ and include both professional and novice musicians and dancers.

In this paper I look at how the Indigenous performers use the Australia Day event to realise their own goals. These goals include, but are not limited to, cultivating Aboriginal performance practices within the urban Indigenous community, and sharing these performances with the wider community. Beginning by exploring the ambiguities inherent in a state sponsored Indigenous performance on Australia Day, I explore how the performers engage with and challenge 'traditional' forms of Aboriginality. I also discuss ways in which the performers create and share cultural knowledge, demonstrating the centrality of creative action and interpersonal relationships in forming an urban Aboriginality.

Through a contextualised and ethnographically informed approach, this paper demonstrates that performance, as a tool for expression, is a form of cultural survival. For the Indigenous performers of Woggan-ma-gule, cultural survival includes physical, cultural, and spiritual aspects, and is creative and communal. In addition, through the act of performance, music and dance, the performers are able to tap in to the creative potential of the Dreaming, ${ }^{3}$ a complex Aboriginal concept described to me as a spiritual force that unites the people and the land, the past, present, and future. Thus, as this paper shows, urban Indigenous people are taking action through creative pathways to revive cultural practices, rejecting discourses of deficit and loss, and replacing them with those of belonging and connection.

\section{ENGAGING AND CHALLENGING NOTIONS OF ABORIGINALITY}

Australia Day is celebrated annually on the 26th of January, commemorating the date in 1788 on which British naval Captain Arthur Phillip (as head of eleven convict ships known as the First Fleet) planted a Union Jack in the soil of what became known as Sydney, claiming the land as a British colony. Following this act, a series of disruptive events began which dramatically changed Indigenous people's lives (Nash 2009). In particular, from the beginning of British settlement, the rights of the original inhabitants of the land were ignored under the Eurocentric doctrine of terra nullius. This doctrine declared that despite the presence of Aborigines, the land belonged to no one. ${ }^{4}$ The Aboriginal people of New South Wales were the first to feel the effects of this change, enduring 'prolonged, hostile and intense occupation of their lands' (Macdonald 2001, 193). 
The assimilation policies that took root in the 1930s were another particularly disruptive aspect of Australia's colonial history. These policies reflected the mind-set of the times that the Aboriginal population needed 'protecting and civilising.' These state policies caused much harm and further propelled the removal of mixed descent Aboriginal children from their families. Known today as the 'Stolen Generation,' these children were abruptly removed from their culture, language and community, an act that has had lasting repercussions for these individuals and their families (Wilson 1997). It is a topic often raised in conversations with the Woggan-ma-gule performers themselves, as many have family members who were survivors of these policies.

As a result of colonial intervention into Indigenous life-ways, there has been a dramatic shift in the practices and patterns of Aboriginal culture and communication (see Cowlishaw 2011; Yamanouchi 2010; Everett 2009). These cultural fissures are reflected in the current social realities of Indigenous Australians, which include significantly higher levels of infant mortality, incarceration, poverty, ill health and a lower life expectancy than those of their non-Indigenous counterparts. ${ }^{6}$ While these figures point to serious social, medical and economic needs, emphasis on the 'gaps' between Indigenous and non-Indigenous Australians (as represented in public discourse and particularly, the media) seems to further enforce notions of Aboriginal culture as dependent and deficient (Gorringe, Ross, and Fforde 2011). Indeed, research undertaken by Chris Sarra examined mainstream Australian perceptions of Aboriginal Australians, and found common usage of such negative descriptors as 'lazy', 'drunks' and 'troublemakers' (Sarra 2010, 197; see also 2005). For the performers of Wogganma-gule, these phrases represent a general lack of understanding of urban Aboriginal culture and are part of the negative stereotype they hope to challenge through their performance.

Along with these negative stereotypes and the ongoing harm caused by colonisation, urban Aboriginal people became characterised by a construction of loss and 'culturelessness' (Beckett 1988; Macdonald 2001) leading to a widespread perception of Sydney's Aboriginal people as inauthentic, especially in comparison to their rural kin (Cowlishaw 2011). Today, the performers of Woggan-magule acknowledge the impact of this colonial legacy, particularly in relation to the differentiation found in the maintenance of Indigenous cultural practices. One performer ${ }^{7}$ categorizes this variation as follows:

We're urban Aboriginals, the ones who live here in the city. Then there's the rural Aboriginals, who live out there, haven't left their country, but they've been moved on to reserves as well. And then 
there's traditional Aboriginals who still live on the country where their old people born 'em, and they're very different because of where they live (Interview, 2011).

Many urban Aboriginal performers feel the burden of the concept of 'tradition' and, as Magowan notes, 'there has often been a special weight laid on Aboriginal culture to be simultaneously 'authentic' in both a Western and an Aboriginal sense' $(2000,314)$. Within this context and its challenges, the performers of Woggan-ma-gule find motivation to make positive contributions to their community and create new concepts of authenticity and identity. For Max Dulumunmun Harrison (Uncle Max), respected elder of the Yuin tribe, Aboriginal culture in NSW is alive; it is 'a living thing.' And so, when speaking to the authenticity of the Woggan-ma-gule ceremony during an interview with me in 2011, he said resolutely, 'it's authentic because they've just done it. Max's words reinforce the view that contemporary Indigeneity is about more than 'preserving traditions;' it is also about having 'the ability to transform' these traditions and their meanings in a context where authenticity is largely regulated by others (Sissons 2005, 15).

Through annual performances of the Woggan-ma-gule ceremony the performers seek to challenge ideas that the Aboriginal people of Sydney are 'lacking in tradition' and replace discourses of authenticity with those of belonging and connection (Sissons 2005). Yet to do this also requires a level of participation in the state's construction of Australia Day. Australia Day, or 'Survival Day' as it has been called, has had a tumultuous history in its attempts to include, willingly or otherwise, Australia's Indigenous population. Indeed, for most of its history, Australia Day has antagonised rather than included the Indigenous people of the country (McAllister 2012). However, following the renewed focus on reconciliation that was occurring in Australia at the turn of the century, ${ }^{8}$ the Nsw government began looking for a way to acknowledge Indigenous Australians on Australia Day in a way that would both recognise the past and advance reconciliation. It was within this context that Rhoda Roberts (Bundjalung), ${ }^{9}$ a prominent figure in the Aboriginal community and an experienced performer, choreographer and journalist, spearheaded the development of Woggan-ma-gule.

Rhoda envisaged creating an Indigenous event on Australia Day that fostered the same reverence as that of ANZAC Day ${ }^{10}$ commemorations. Rhoda hoped to create a public ceremony that respected the ancestors and acknowledged an Indigenous perspective of Australia Day (Koori ${ }^{11}$ Mail 2004). She felt the best way to promote equal citizenship on Australia Day was to 'have inclusion 
in major mainstream celebrations, rather than being quite separate' (Koori Mail 2004) as other Indigenous Australia Day events had been in the past. ${ }^{12}$ Under Rhoda's artistic direction, and with funding and sponsorship from the Australia Day Council of Nsw, the first performance of the Woggan-ma-gule Morning Ceremony was held on Australia Day, January 26th, 2003. The Woggan-ma-gule ceremony is successful in part, because it simultaneously fulfils the goals of the state and the Indigenous community.

McAllister, who has undertaken studies on both Australia Day and Waitangi Day, points out that many 'national day rituals are authored by states, to portray and reinforce a common imagination of nation' $(2012,18)$. Thus, it is not surprising that on Australia's national day, the state is primarily concerned with promoting nation-building narratives. By providing the public with an event like Woggan-ma-gule, the state gives the appearance of being inclusive of Indigenous peoples and their traditions. McAllister also acknowledges that, 'performance can both reproduce aspects of the dominant social order and subvert it at the same time' (McAllister 2012, 18). Indeed, Woggan-ma-gule can be seen both as an accommodation of state-sanctioned representations of Indigeneity in its nation building project, and as a form of resistance to dominant public stereotypes of urban Indigeneity as inauthentic and 'cultureless.' It is the latter that resounds most prominently in discussions with the performers, who acknowledge that the state may have its own agenda, yet continue to express their gratitude for the opportunity to perform their Indigeneity publicly on Australia Day. During an interview with me in 2008, performer Tim Bishop commented on how it feels to represent his people and their cultural survival on Australia Day, saying, 'to acknowledge that through something that I love doing, dancing, it makes me wanna do back flips!' Another performer described performing on Australia Day as 'an important way of making visible the invisibility' he feels is experienced by many urban Indigenous people in their everyday lives (Interview, 2008).

The process of creative action is empowering. Drawing on the possibilities of imagination, it is a cultural resource for challenging norms, for resistance, for going beyond a certain situation. As French philosopher Sartre put it, imagination enables individuals to escape being 'swallowed up in the existent;' it frees them from given reality and allows them to be other than how they might seem to be made (1972, 273, quoted in Rapport and Overing 2000, 4). Creativity is used by the performers 'to express their cultural distinctions as part of a process of reclaiming their identity in a world that had tried to distinguish them' (Hendry 2005, 195). As the following sections show, participation in Woggan-ma-gule provides community building and identity affirming 
action. 'It is through the practice of ritual - through performance - that belonging is 'anchored' and made tangible (Lovell 1998,10) and that meaning is made' (McAllister 2012, 78). For the performers of Woggan-ma-gule, cultural performance provides an outlet to demonstrate and celebrate their identity, creativity and hope.

CREATIVITY, CULTURAL KNOWLEDGE AND ABORIGINAL PERFORMANCE PRACTICES

One of the ways an urban Aboriginality has been formed is by drawing on the cultural knowledge of other Indigenous groups. The urban-based performers of Woggan-ma-gule often collaborate with their rural networks as a creative resource in developing performance pieces. This inter-Indigenous form of cultural sharing is common in Sydney and is practiced by the leading Indigenous performing arts school, National Aboriginal Islander Skills Development Association (NAISDA) Dance College, and renowned Indigenous performing arts company, Bangarra Dance Theatre. Cultural consultants can be from nearby, like Uncle Max of the Yuin of the south coast of Nsw, or further afield, like Yolngu elder Kathy Marika from northeast Arnhem Land. Kathy is proficient in Aboriginal performance and craft and is also a cultural consultant for NAIsDA Dance College and Bangarra Dance Theatre.

In 2008, Kathy performed in the Woggan-ma-gule ceremony at the invitation of its Creative Director, Peta Strachan ${ }^{13}$ (Dharug/Boorooberongal). Kathy instructed the creative team in performance pieces by drawing on her own lived experiences. During rehearsal for a performance piece entitled Wild Yam, Kathy demonstrated the technique of harvesting yams to a group of young performers, showing the girls how she would follow the yam vine and search for its fruit by digging in the ground. The group of young female dancers, who envisaged collecting the yams based on Kathy's demonstrations and descriptions, then recreated this process with her performatively, simulating the actions involved in following the vine and digging up the yam. The professional female cast then rehearsed a contemporary interpretation of this same process, further expanding the movements and forms through dance. Kathy's belief in the importance of dance and the sharing of culture helped her overcome initial concerns with performing outside her own community and in an urban environment. Kathy reflected: 'Sydney is in a stage of surviving now. They're growing, where they thought they had nothing, through people like me helping them, giving a little taste here and there. Like putting a seed in the ground and letting it grow' (Marika, Interview, 2008). 
Learning from elders such as Kathy Marika, who carry extensive knowledge of Aboriginal performance, is a process that facilitates relationship-building and the sharing of knowledge. This knowledge then acts as a 'traditional base' from which performers can develop 'contemporary work, around it, through it, as a part of it' (Bishop, Interview, 2008). Woggan-ma-gule combines both traditional and contemporary dance and song forms, and has done so intentionally and consistently from its inception. This reflects the training background of the performers and their desire to both honour the past and develop a vibrant future for Indigenous performance in Australia. Contemporary dance styles compliment traditional Aboriginal dance forms well. This combination of dance styles has led to an increase in the range of movements in the Indigenous performance vocabulary. For example, contemporary female movements include spins, leaps, and lifts, and tend to be less weighted than traditional movements, where the body remains more grounded.

The stories the performers tell through their performances are distinctly Aboriginal, dealing with Indigenous stories and subjects in performatively meaningful ways. The performers regularly incorporate creation or Dreaming stories into Woggan-ma-gule narratives, along with other significant issues to the Aboriginal community. The topic of the Stolen Generations has been a feature of multiple Woggan-ma-gule performances, highlighting the ongoing relevance of this period for Indigenous Australians. The 2008 performance addressed the heartbreak caused by the effects of the Stolen Generations, when kinship bonds were broken and children were removed from their mothers. With a strong narrative content emphasized by the music of Songwoman Emma Donovan, the performance piece ended by symbolically reconnecting the children with their mothers. Other themes such as the struggle for Land Rights have also been approached through performance. For the 2009 event, the performers planted an Aboriginal Flag in the sand, symbolically reclaiming the land (Bright 2011) and highlighting the event's ability to redirect projects of settler nationhood (Sissons 2005).

The local Gadigal people called the area on which the ceremony is now held, 'Woggan-ma-gule', which refers to the place where fresh and salt waters meet. The site was used pre-colonisation for initiation ceremonies by the Gadigal ${ }^{14}$ who, before being devastated by introduced disease, lived in the area now occupied by the Royal Botanic Gardens and the iconic Sydney Opera House. The performers honour the Gadigal people's connection to the land by engaging in a continuity of Aboriginal performance practice on the Woggan-ma-gule site.

For the performers of Woggan-ma-gule, contact with the natural elements 
through the human body is described as central in maintaining and respecting a connection with land, allowing them to 'feel the spirit in the earth' (Slockee, Interview, 2011). The natural environment is therefore incorporated into the Woggan-ma-gule performance in a variety of ways. Most notably, as a key representation of Aboriginality, all performers are painted in ochre - coloured clay mixed with water. The performers believe that the application of the clay to the body connects them to the earth, and through the earth to the spirit of their ancestors. For them, the relationship between body, earth and spirit is a central component of Indigenous performance and identity.

'Painting up' is a phrase used to denote the process of decorating the performers' bodies with ochre. For the performers of Woggan-ma-gule the process of painting up involves both creativity and intuition, renewing the traditional symbolism and communication of body painting through contemporary performance. Many of the professional dancers have their own personal ochre designs that have particular and sometimes private meaning. Dancer and choreographer Tammie Jarrett and her brother, singer-songwriter WireMC, performed in the 2009 ceremony and painted each other in family specific iconography. Songman Matthew Doyle (Muruwari) uses a white clay wash as a base for his body design, adding brown and red to represent the Lyrebird, which holds meaning for him as his totemic animal. The Doonooch dancers, who are regular guest performers in the event, ${ }^{15}$ have a special process in painting up, which is 'men's business' and conducted in private. The white and red ochre patterns adorning their skin depict different stages of the growth of an Owl, the totem of the Doonooch dancers, whose name means 'Owl Dreaming. For these performers the painting up process prior to the performance is carried out with great reverence and facilitates their connection to the land, ancestors and Dreaming.

Before the performance commences, the performers gather in the courtyard for a Performers Circle, where the entire cast stands together as one in a large circle. They clasp hands as a symbol of cohesion, and the leaders share their final pre-performance thoughts and reflections. In 2007 Songman Matthew Doyle addressed the group, reflecting on the past and the significance of the present with the following words: 'We might look differently, but the main thing is that we're here, representing our people and also paying respect to the original people of this land, the Gadigal. Remember that. Go out and do your best. Enjoy yourselves.' Performer Clarence Slockee ${ }^{16}$ (Bundjalung) concluded the 2007 Performers Circle by encouraging everyone to remember the importance of the ceremonial site, saying, 'The Gadigal people had ceremonies in this place for thousands of years. Just like all of our ancestors in our own places. 


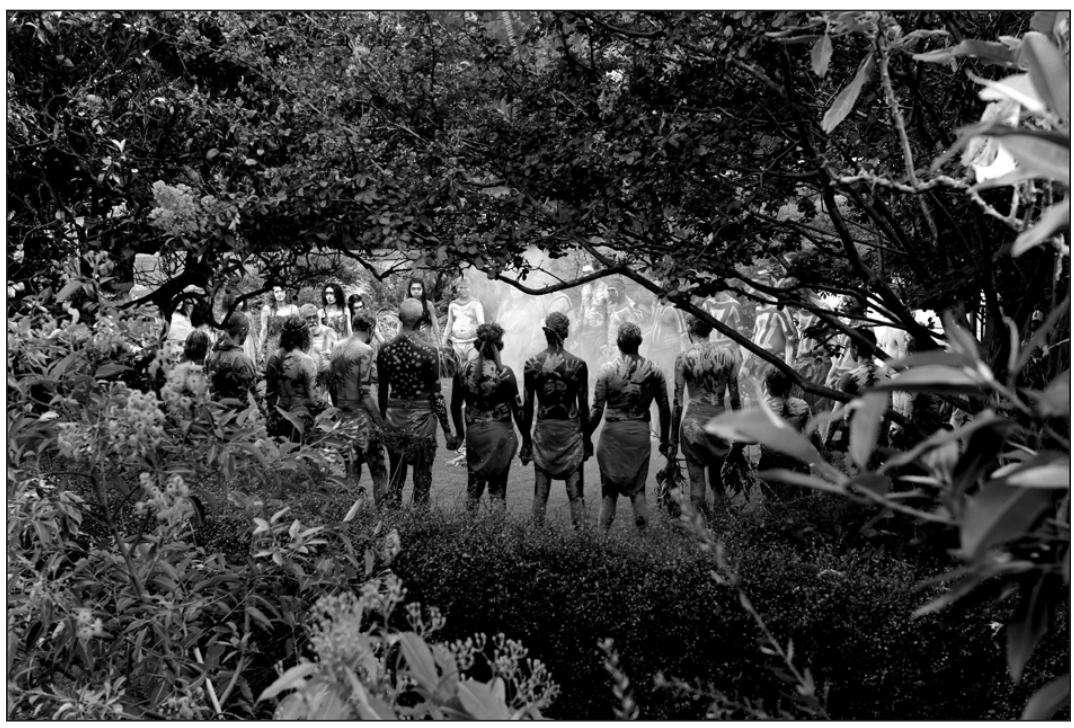

Figure 1. Woggan-ma-gule Performers Circle, 2011 (Source: AAP/Tracey Nearmy).

Dance strong and be proud of who you are and where you are today. Lets have a good one, ay!' Following the Performers Circle, the performers begin their procession down to the sand circle performance site where the audience awaits, both groups filled with a sense of excitement and anticipation.

Since its debut, the use of Aboriginal language during the performance has functioned as a marker of Indigeneity. Many of the performers have spent time incorporating language in to their performance repertoire and there is common interest in sharing this knowledge. The use of Aboriginal language in Woggan-ma-gule highlights its cultural and performative importance, reflecting its increasing prominence in the Sydney area. Songman Matthew Doyle sings entirely in language, ${ }^{17}$ but addresses the audience in English when giving a welcome or acknowledgement. Regular guest performer and singer-songwriter Emma Donovan uses both English and the Gumbayngirr language of Nsw during her songs, and other Songwomen and Songmen have sung either entirely in English or in language. Multilingualism is therefore an important part of the Woggan-ma-gule performance; ensuring part of the verbal content is accessible to an English speaking audience, while simultaneously exposing those present to Indigenous language. 
A Welcome to Country has become an important part of ceremonial protocol at public events in Australia. ${ }^{18}$ Typically, it is a succinct symbolic statement welcoming guests to Aboriginal land. In 2007, Songman Matthew Doyle offered the following Welcome to the Woggan-ma-gule audience:

I'd like to welcome you today to this very special place, native name: Woggan-ma-gule. This is a special place for the Gadigal people, of the Eora. ${ }^{19}$ A space where ceremonies did take place, and over the last few years we've revived that tradition by continuing to practice and teach our culture, and share our culture, with all Australians.

Matthew then went on to speak a few words from Gadigal (Eora) language, which he translated as meaning 'we welcome you to this land, our home, and extend our hand in friendship.' Matthew's welcome was met with applause from the audience, and established the inclusive spirit of the ceremony.

PERFORMER AND AUDIENCE INTERACTION - A CEREMONY FOR EVERYONE

In Aboriginal and Torres Straight Islander ceremony, everybody is involved. It's all one big thing... it's a ceremony for everyone to be involved in. (Clarence Slockee, addressing audience, Woggan-magule Ceremony 2007)

The Woggan-ma-gule audience is culturally diverse and includes family and friends of the performers, members from the wider community (both Indigenous and non-indigenous) and many visitors from other parts of Australia and the world. Some audience members have come every year, others merely 'happened by' the performance on a morning walk through the gardens. Regardless of where they originate, the ceremony offers the audience a chance to engage with Aboriginal performance on Australia Day and experience an event which is, in the words of one audience member, 'amazingly beautiful and powerful.'

Valuing the Aboriginal cultural principle of inclusiveness, the performers of Woggan-ma-gule aim to incorporate the audience in the ceremony in several ways. This begins with the smoking ceremony that offers a cleansing for everyone. During the performance, the audience encircles the performers, meaning that the spectators can see each other across the sand stage and are aware of the communal experience of the performance. In addition, the distance between the performers and audience is very close, and those sitting directly around the perimeter of the sand circle can easily see the facial expressions of the performers and feel the rush of air caused by their movements. This visual 


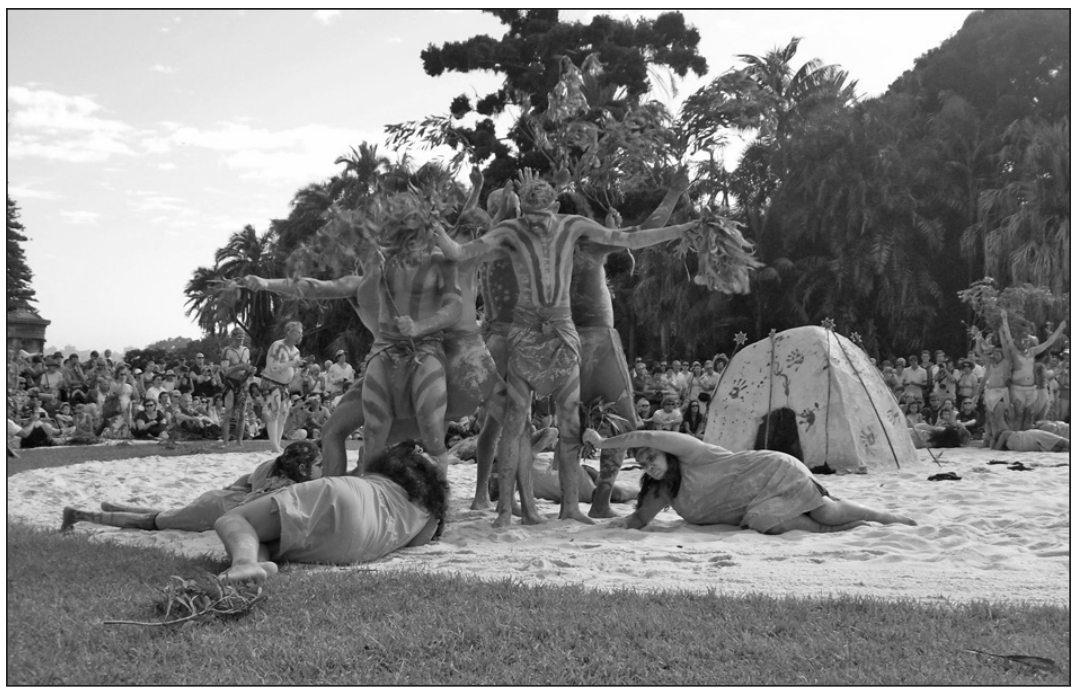

Figure 2. Woggan-ma-gule Morning Ceremony, 2011 (Source: Author's collection)

and physical proximity has the effect of drawing in the audience, an experience that one audience member described as being 'both etheric and tangible.' Finally, the performers hope to invoke a sense of inclusiveness through time shared together in interaction and dialogue following the main performance. The following example, taken from the 2007 event, illustrates this interaction and briefly examines some of the outcomes for both the performers and audience members.

Following the closing dance sequence of 2007 , the performers received a loud and long applause from the audience. While the rest of the cast sat on the edge of the circle, performer Clarence Slockee ${ }^{20}$ took to the centre of the sand circle with a microphone. In an embracing and engaging tone he addressed the audience:

Good morning and thank you very much ladies and gentleman for that lovely, lovely round of applause and the warmth that we're feeling from the crowd this morning, on this bittersweet day for Aboriginal people. But we are here to celebrate; the fact that we're still here and the fact that we're still practicing culture.

My name is Clarence Slockee; I'm a Bundjalung man, Mindjingbal 
Clan, up on the far north coast of Nsw. I'm a salt-water man. It's very nice to be here in salt water, Woggan-ma-gully, where the fresh water meets the salt.

This would have been a beach 200 years ago so it's apt that we're on the sand. And the ceremonies would have actually happened down here on low tide, so we are reinvigorating some of the culture and letting people know what happened on this site.

After Clarence had acknowledged the performers and crew he invited the audience to ask questions relating to both the Woggan-ma-gule performance and Indigenous Australia generally. This period, known as the Question and Answer (Q \& A) session is another way the audience is included in ceremony. From a little girl asking what Boomerangs are for, to more poignant questions such as how to say 'Sorry' in Aboriginal language, questions asked by the audience show that they are interested in the culture, treatment and acknowledgment of Indigenous people in Australia (Bright 2011).

The Q \& A evolved as a formalized response to interaction taking place following the first few ceremonies, where audience members remained in the performance area and mingled with the performers, invariably asking questions relating to the performance. As Narelle Lewis, the Event Coordinator for the 2007 ceremony, said, '... people do wanna know 'what does the Aboriginal flag mean?' Really simple, simple questions, but it allows them a forum to ask things that maybe they wouldn't ask anywhere else' (Interview, 2007). Indeed, time allocated for a Q \& A session offers a space for audience members to interact with Indigenous Australians and ask questions, an opportunity that many have simply never had before.

In 2007, a man sitting near the front with his two children posed this question: 'Just wondering what us non-Indigenous Aussies can do to support our Indigenous brothers and sisters?' Clarence's response was as follows: 'All we ask is that we are given a fair go and that we aren't stereotyped.' His statement reinforced one of the driving motivations of the Woggan-ma-gule performance to present the audience with a positive image of Aboriginality in an effort to counteract prevalent negative stereotypes.

This brief yet significant forum of interaction facilitates positive educational and social outcomes for those present and is a distinguishing feature of the event's urban setting. In particular, this time encourages understanding and promotes interest in Indigenous Australian culture and people. Acknowledging 
this, an Aboriginal audience member ${ }^{21}$ expressed her gratitude to the performers for 'practicing culture' both through performance and in their everyday lives, and for showing other Australian's that 'we are still alive.' Her words directly echo Clarence's opening statement and emphasize the representational concerns of the Aboriginal people of Sydney.

Following the Q \& A session, the ceremony concludes and the audience moves from their places. Many of the performers and members of the public continue their interactions, intermingling over the sand stage. This time is also used to record memories of the event through the medium of photography. The children in particular enjoy having their photographs taken by and with members of the audience. Proud parents and other relatives of the performers also take pictures. Walking through the crowd of audience members, performers, media and invited dignitaries, one hears many comments of gratitude: 'Thanks for a wonderful performance, we really enjoyed it;' 'Deadly moves Sis';' 'it's so great to be able to do this and share our culture.' These moments of interaction on the ceremonial sand stage embody the inclusive intentions of the Wogganma-gule event.

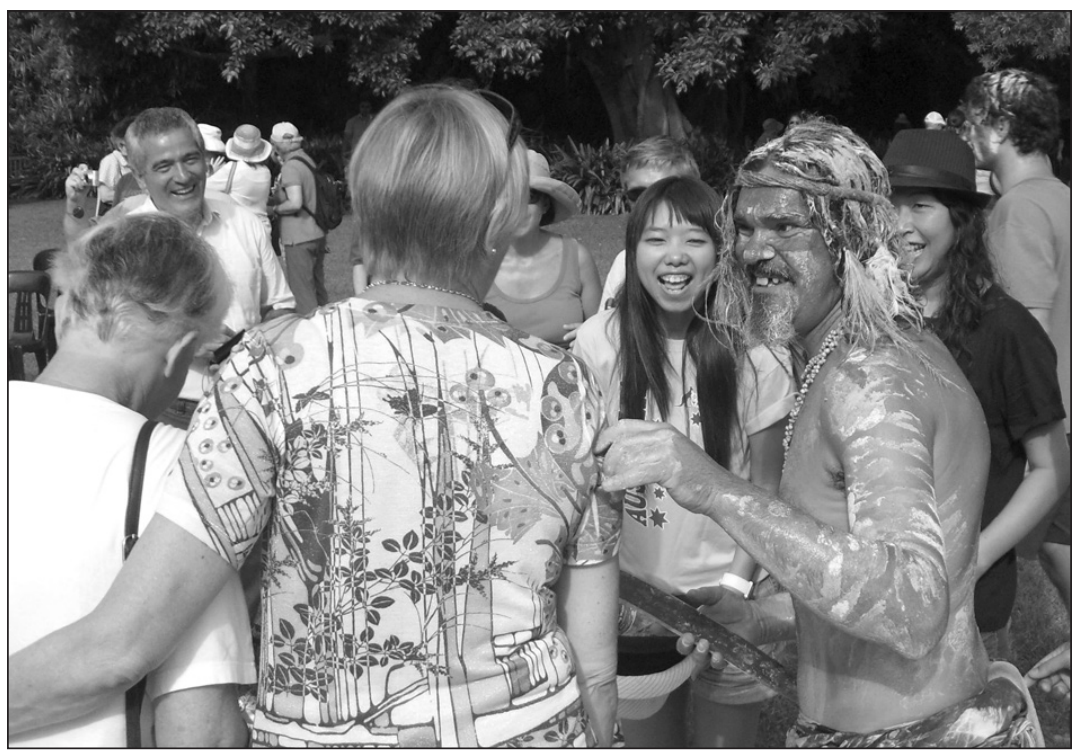

Figure 3. Performer Glenn Doyle (Right) interacts with audience members following the 2011 ceremony (Source: Author's collection). 
A POSITIVE VISION OF URBAN ABORIGINALITY: BUILDING COMMUNITY AND EMPOWERING YOUTH

The Woggan-ma-gule ceremony and rehearsals create an Aboriginal space where positive visions of urban Aboriginality can be shared. For the performers and their kin this vision includes empowering future generations of Aboriginal Australians to connect with their Indigeneity through creative pathways, interpersonal bonding and community collaboration.

Annual performances over the last 10 years have seen the establishment of a 'Woggan-ma-gule Family,' a core group of performers and their supporters who come together every year to perform ceremony. This family is made up of professional Aboriginal performers and novices young and old who share a common desire to participate in cultural performance on Australia's national day. Even after the performance of Woggan-ma-gule has come and gone, the Woggan-ma-gule family remains connected to each other. The performers will come together again in the coming weeks to watch a video of the performance, the professional dancers continue to collaborate on other projects, and the youth see each other at school or social events.

The centrality of family to Aboriginal culture is repeatedly demonstrated through the words and actions of those participating in the Woggan-ma-gule rehearsals. During rehearsals performers are accompanied by an assortment of non-performing supporters including parents, siblings and dependent children. These supporters provide encouragement, sustenance and envelop the performance in a sense of community. Although never appearing on stage, they play a pivotal role in the success of the event.

Within the rehearsal space Aboriginal practices link everyone together in a social group. These practices most commonly include the sharing of food, caretaking and resources. Collaborative caretaking of the youngest members of the Woggan-ma-gule family is common practice, particularly when the primary caregiver is needed to rehearse. Infants and toddlers are given abundant care and affection by all, though adolescent females are often quick to take up the task. This practice means that high degrees of interpersonal socialisation occur within the Woggan-ma-gule group, extending the kinship network beyond immediate bloodlines. The sharing of food, is another form of demonstrating this commitment to relationships. During lunch breaks a 'what's mine is yours' attitude ensures no one is left without. Humorous dialogue is regularly heard during these breaks, with good-natured teasing and banter common among the adults and the youth. 
Rehearsals are an important social opportunity for the youth to socialise, play games and develop friendships (McIntosh 2006). As well as practicing for the performance, the time spent together during breaks in rehearsals also contributes to the interpersonal bonding amongst the youth of Woggan-magule. During breaks the youth enjoy playing games with each other, regularly engaging in athletic and creative activities. The young performers showcase their talents in other dance forms, particularly hip-hop, demonstrating their aptitude for movement mimicry. Personal items such as cell phones and iPods become a social axis as the latest song or music video is shared amongst peers. Time spent together during rehearsals reinforces feelings of belongingness and sustains a shared sense of Aboriginality.

The social interactions, including ways of talking and ways of childrearing exhibited during rehearsals, are ultimately ways of being Aboriginal. Consequently, for the performers of Woggan-ma-gule, rehearsals prior to the event itself become an important aspect of Aboriginal social life. The following quote illustrates this familial bond, and was spoken with great affect by Songman Matthew Doyle as he stepped in to the performance circle where the rest of the cast was seated during a rehearsal for the 2009 ceremony: 'In this circle, we're all family. No matter where you come from. Peta's my sister, not my blood sister, but she's my sister, her daughters are my daughters. And here in the circle, are all my family.'

A respected member of the Indigenous community of Sydney, Matthew Doyle has participated in Woggan-ma-gule since its inception in 2003, performing as Songman, and contributing to the choreography and mentoring of the young Aboriginal performers. As a successful musician and dancer, Matthew has collaborated with many performers over the course of his career and developed a robust knowledge of Aboriginal language and culture. Like many other Indigenous Australians, Matthew did not always know of his Aboriginal heritage. His mother, her sisters and his grandmother left the bush when his mother was still very young and moved to Sydney. Matthew and his brother began asking if they were Aboriginal after getting teased in school. In an interview with Koori Radio, Matthew comments:

My grandmother denied it for a long time because back in those days Kooris weren't allowed to marry whitefellas. She used to tell people she was Spanish. When she finally told us, I started to find out about my heritage and identity (24 January, 2007).

Matthew then embarked on a journey of discovery and enveloped himself 
in Indigenous music and dance. At the age of 16 he began his studies at an Indigenous performing arts school, part of which involved visiting different Indigenous communities in Northern Australia. Doyle went on to be a founding member of the Aboriginal Islander Dance Theatre's (AIDT) professional company. His personal journey is significant in that it illustrates the positive outcomes that are possible for Indigenous individuals and communities through engagement with cultural performance. Now a mentor and guide for the next generation, Matthew is passionate about passing on the knowledge he has gained. He says, '.... if the ceremony continues into the future hopefully they'll be the one's taking over and keeping it alive. They'll have different stories to tell, or new stories to tell, and that's the way forward' (Interview, 2011).

Aboriginal youth engaging in Aboriginal forms of performance is an explicit way to publicly demonstrate the continuity of Aboriginal culture. Yet, the presence of youth also represents change, as not all of the Aboriginal children of Woggan-ma-gule share the same phenotype; some have blonde hair and blue eyes, challenging mainstream preconceptions of what an Aboriginal person looks like. A mother of two young performers encourages her 'lighter skinned' children in the Aboriginal arts as she feels it ultimately protects them from the effects of criticism. She believes that participation in Woggan-ma-gule provides her children with 'a better sense of themselves so that when people are negative they can know in their hearts what it is to be Aboriginal' (Interview, 2011). The adult performers are intent the youth of Woggan-ma-gule learn that being Indigenous is about more than skin colour. They achieve this through instilling a sense of cultural pride based on participation in the rehearsals and ceremony (Bright 2011, 263).

Final preparation of props and costumes often occurs on the sidelines of rehearsals and is another important time where social bonds are strengthened and cultural knowledge shared. Those performers not dancing work together with the supporting members of the Woggan-ma-gule family to make items such as armbands and headbands, which are used during the performance. Dean Kelly makes many of the props for Woggan-ma-gule, and in 2011 performed in the ceremony for the first time, joining his wife Calita Murray and their children. Dean works for the Nsw National Parks and Wildlife Service (NPWs), and this association has been significant for the Woggan-ma-gule family, facilitating many group fieldtrips to collect materials for the performance and to further develop a relationship with the local landscape. Clarence Slockee and the children will also collect flax from the Botanic Gardens along with a variety of leaves and kindling to be used in the smoking ceremony. All involved in these expeditions express great satisfaction in this process. These 
activities along with onsite rehearsals help in connecting the performance to the landscape, establishing a continuing association with country.

Dean and Calita, along with other Woggan-ma-gule parents, are active in the cultural education of their children. Calita, a graduate of NAISDA, works as an Aboriginal Education Officer at a local school, where her children and those of several other performers attend. Here, she has developed an Indigenous dance group where many of the young Indigenous students have their first experiences with Aboriginal performance. Parents like Dean and Calita view participation in Woggan-ma-gule as an opportunity for their children to gain important understanding of their Indigenous heritage. As Calita said:

I feel proud, as a mother, to be able to watch my children learn about their culture. Growing up as a kid, even though in my family the culture stayed strong, when you went to school you weren't allowed to learn about Aboriginal culture, it was all hidden under the carpet (Murray, Interview, 2011).

Many of the adult performers speak of the considerable generational shift in the mainstream acknowledgement of Aboriginality in Sydney, reflecting that their own offspring have more opportunities to learn and engage with their Indigenous heritage than those generations directly preceding them. Matthew's comment to me during an interview is illustrative:

This is a good time for us and our kids, to give them an opportunity to learn about their culture, by all of us coming together and by telling those stories like we have done for many thousands of years, through our songs and language and dance (Doyle, Interview, 2011).

Engaging in Aboriginal performance continues traditional practices, and at the same time cultivates new forms of Aboriginality that acknowledge the social realities of urban Indigenous youth. During rehearsals for the 2011 performance, Yuin Elder Uncle Max shared Dreaming stories with the young performers. Uncle Max encouraged them to create their own 'Modern Day Dreaming' by connecting with the world around them, whatever that world might be. He conveyed to them their own agency by saying: 'Within your own bodies, lies the power to create, through dancing and connecting with spirit.' As far as Max was concerned, it was up to them to decide on the form this Dreaming would take. 


\section{CONCLUSION}

While Indigenous cultural forms have and continue to be appropriated within the context of settler nationhood, performances like Woggan-ma-gule also provide individuals and communities with a way of challenging dominant discourses of Indigeneity. Participation in Australia Day through creative action not only demonstrates the power and skill of Indigenous art forms, but also asserts the Indigenous aspect of Australian nationhood. Through conveying significant Indigenous narratives, the performance and the subsequent interaction between audience members and performers ensure Aboriginal history, culture, and values are shared and made visible.

As this paper has shown, mentoring from elders empowers the urban-based performers of Woggan-ma-gule to create new forms based on traditional cultural practices. These forms, which incorporate both traditional and contemporary dance and musical styles, are distinctly Aboriginal. Performers' personal and spiritual bonds are strengthened through performance practices, including the process of 'Painting Up' and participation in the Performers Circle. In addition, preparation and rehearsals prior to the final performance are an integral part of the Woggan-ma-gule ceremony, revealing Aboriginal culture in its everyday sense. Through an ethnographic exploration of the intersections between imagination, performance and cultural survival, this paper has demonstrated ways in which the Woggan-ma-gule performers are creatively engaging with urban Aboriginality and demonstrating their sense of belonging and hope.

\section{ACKNOWLEDGEMENTS}

This paper is based on a presentation given at the 2012 ASAA/NZ conference, Anthropology and Imagination, in the panel 'Identity, Creativity and Hope'. I'd like to thank the Association of Social Anthropologists of Aotearoea New Zealand's Kakano Fund for assistance in attending the conference, and the University of Canterbury and the Building Research Capacity in the Social Sciences (BRCss) Network for providing scholarships for the research on which this paper is based. This paper has benefitted from comments made by Lyndon Fraser and Patrick McAllister whose feedback and encouragement during its various stages is sincerely appreciated. Thanks also to the reviewers for their thoughtful and insightful comments. Immense gratitude must also go to my family, for their generous and enthusiastic support of my academic adventures. 
NOTES

1 The ADCNsw, through the office of Protocol and Special Events (PSE), provides the production, publicity and administration for Woggan-ma-gule.

2 Since its debut in 2003, the Woggan-ma-gule ceremony has grown in both attendance and in the number of performers involved, particularly youth. At a peak number in 2009 there were 59 performers involved and 41 of those dancers were under 18 years old. This increase in young performers reflects one of the developing goals of Woggan-ma-gule, which has been to incorporate and facilitate the training of Aboriginal youth in the Indigneous performing arts.

3 The word Dreaming refers to Aboriginal understandings of creation and connection. Hokari, who conducted in-depth research on Gurindji cosmology, describes the complex and multidimensional nature of the concept as 'a web of connection between Dreaming beings, people and their countries and ceremonies' $(2001,59)$.

4 Terra nullius was finally overturned by the High Court of Australia in the ruling Mabo v. Queensland (No. 2), 1992.

5 These policies were, in fact, carried out over many 'generations' as Aboriginal children were removed from their families by the Commonwealth and State governments of Australia between the early 1900s and the 1970s. On the Stolen Generations, see Wilson (1997).

6 The Australian Bureau of Statistics (ABS) released figures in 2009 indicating that the average life expectancy gap between Indigenous and non-Indigenous Australians was around 11 years. Reconciliation Australia notes in its 'Closing the Gap - Life Expectancy' factsheet that although 'the figure has moved from 20, to 17 , to 11 years due to the use of various methodologies' this is not indicative of 'an actual improvement in the life expectancy of Indigenous people' (14 April, 2010, 2).

7 Participants are cited using their real names. However, in some instances, names have been omitted to protect the privacy of these individuals and their families.

8 The 2000 Sydney Olympics saw a broadening of cultural awareness, a widespread sense of national pride and increased focus on Indigenous culture and performing arts.

9 In some instances the Aboriginal language group(s) individual performers 
identify with have been listed following the first mention of their names. These associations convey the Aboriginal language group/nation from which the performers descend and are often listed in performance programs, including those for Woggan-ma-gule.

10 ANZAC refers to the Australian and New Zealand Army Corps formed during the First World War. Today, both countries commemorate ANZAC Day on the 25th of April, with events held at local war memorials and community halls to honour all veterans who have served and died.

11 The term Koori refers to Indigenous people from South-eastern Australia (Nsw, Victoria and Tasmania).

12 The first 'Survival Concert' was held in 1992 at La Perouse and arose as an alternative event to mainstream celebrations of Australia Day. Today, its successor, the Indigenous festival, Yabun (meaning 'Song with a Beat' in the Eora language), is one of the biggest Indigenous events in Australia, with a strong focus on celebrating the ongoing survival of Indigenous cultures.

13 Peta Strachan stepped in to the role of creative/artistic director of Woggan-magule in 2007 when she and fellow choreographer Thelma Parker took on the job following Rhoda's departure. Graceful and athletic, Peta trained in dance from an early age. After studying at NAISDA Peta performed with the Aboriginal Islander Dance Theatre (AIDT) with whom she travelled internationally. She joined Bangarra Dance Theatre in 2000 and afterwards free-lanced in the Sydney area, working with the Garrabarra Dance Company under Rhoda Roberts, and as a performer in Woggan-ma-gule. Peta is the founder and current creative director of Jannawi Dance Theatre, a Sydney based company nurturing the next generation of Indigenous dancers.

14 A Gadigal male initiation ceremony, known as Yoo-lahng erah-ba-diang, was held on the Woggan-ma-gule site up until the late 179os. David Collins, who sailed with the First Fleet and became the colony's first judge advocate, documented the ceremony in An Account of the English Colony in New South Wales (1798).

15 An all-male group from the South East Coast of Australia, the Doonooch Dancers are annual performers in Woggan-ma-gule and have participated in cultural events and arts festivals both nationally and internationally. Led by Songman Cecil McLeod their vocalizations and body movements are enthralling and at times startling. The Doonooch Dance Company was founded in the early nineties by Robert (Uncle Bobby) McLeod, Aboriginal musician, author and 
respected elder. Robert McLeod's belief that culture was critical to improving Indigenous wellbeing (see Australia Council, 200o) led him to establish the dance program for Aboriginal men and youth. Now a multi-generational dance company with strong kin and community ties, the Doonooch Dancers represent the fully realized vision of the empowering potential of mentoring and collaboration.

16 Aboriginal Education Officer for the Sydney Royal Botanic Gardens, Clarence has been a key figure in the development of Woggan-ma-gule and its ongoing relationship with the Botanic Gardens as the site of the ceremony. Clarence is passionate about Indigenous culture and the potential of future generations, which has led him to a wide range of community roles.

17 'Language' refers here to various Aboriginal languages of the Sydney area, including the recently revived Dharug language, and the Eora language which encompasses the Gadigal dialect.

18 See Everett (2009) for an interesting exploration of this performance practice in relation to the state. Everett contends that practices like Welcome to Country are ways 'in which an idea of Aboriginal country can be included in state representations without legal or political consequences' (2009, 58, emphasis in original).

19 Eora means 'the people,' and refers to the Eora Nation, a language group of the Sydney area.

20 Clarence's enthusiasm for education, his experience with the public and comfort with oration, made him the ideal individual to lead this part of the ceremony. Complementing his more poignant replies, Clarence's ability to interject humour into the Q \& A interaction was uplifting. He had the audience in stitches with his answer to a question on the male loincloths, saying 'Particularly around Gadigal area, the men would just have a strip of possum skin, a possum tail. [Adding cheekily] Some men would have bigger possum tails of course!'

21 A member of the Stolen Generations, this woman also expressed to the audience that they would be 'putting Sorry back on to the agenda.' Indeed, on 13 February 2008, Australia's then Prime Minister Kevin Rudd made an official Apology, which was broadcast live across Australia. See Rudd (2008).

\section{REFERENCES}

Australian Bureau of Statistics (ABS). 2009. 'Experimental Life Tables for Aborigi- 
nal and Torres Strait Islander Australians, 2005-2007', cat. no. 3302.0.55.003, Canberra: ABs.

Australia Council. 200o. Australia's Indigenous Arts. http://www.australiacouncil.gov.au/resources/reports_and_publications/artforms/indigenous_arts/ australias_indigenous_arts

Beckett, Jeremy. 1988. 'The past in the present; the present in the past: constructing a national Aboriginality.' In Past and Present: The Construction of Aboriginality, edited by Jeremy Beckett, 191-217. Canberra: Aboriginal Studies Press.

Bright, Angel. 2011. 'The Woggan-ma-gule morning ceremony' In First World, First Nations: Internal Colonialism and Indigenous Self-determination in Northern Europe and Australia, edited by Günter Minnerup and Pia Solberg, 256-266. Eastbourne: Sussex Academic Press.

Collins, David. 1798. 'An account of the English colony in New South Wales: with remarks on the dispositions, customs, manners, \&c. of the native inhabitants of that country. To which are added, some particulars of New Zealand / compiled, by permission, from the mss. of Lieutenant-Governor King.' London: Printed for Cadell and Davies.

Cowlishaw, Gillian. 2011. 'Mythologising culture part 2: Disturbing Aboriginality in the suburbs.' The Australian Journal of Anthropology 22:170-188.

Everett, Kristina. 2009. 'Welcome to country...not.' Oceania 79 (1):53-64.

Gorringe, Scott, Joe Ross and Cressida Fforde. 2011. 'Will the real Aborigine please stand up? Strategies for breaking the stereotypes and changing the conversation.' Australian Institute of Aboriginal and Torres Strait Islander Studies (AIATsis) Research Discussion Paper No. 28, Canberra. http://www.aiatsis. gov.au/_files/research/AIATsisDiscussionPaper28.pdf

Hendry, Joy. 2005 Reclaiming Culture: Indigenous People and Self-Representation. New York: Palgrave Macmillan.

Hokari, Minoru. 2001. 'Cross Culturalizing History: Journey to the Gurindji Way of Historical Practice.' Unpublished Doctoral Dissertation, Canberra: Australian National University.

Koori Mail. 2004. 'Sharing our history', Feb 11, 319:40. http://www.aiatsis.gov.au/ 
koorimail/issues/o1-05.html\#2004

Koori Radio. 2007. 'Paulette and Nathan interview Matthew Doyle' Koori Radio, January 24, 2007.

Mabo v. Queensland (No. 2) 1992. High Court of Australia 23; 175 CLR 1 F.C. 92/o14 (3 June 1992) High Court Registry, Canberra. http://www.austlii.edu.au/au/ cases/cth/HCA/1992/23.html

Macdonald, Gaynor. 2001. 'Does 'culture' have 'history'? Thinking about continuity and change in central New South Wales'. Aboriginal History, 25:176-199.

-1991. 'Art as power: art, music and dance in the lives of Australian aboriginal peoples.' The Journal of Social Science 30(2):57-78.

Magowan, Fiona. 2000. 'Dancing with a difference: Reconfiguring the poetic politics of Aboriginal ritual as national spectacle.' The Australian Journal of Anthropology 11(3):308-321.

McAllister, Patrick. 2012. National Days and the Politics of Indigenous and Local identities in Australia and New Zealand. North Carolina: Carolina Academic Press.

McIntosh, Jonathan. 2006. 'How dancing, singing and playing shape the ethnographer: research with children in a Balinese dance studio.' Anthropology Matters Journal 8(2):1-17.

Nash, Daphne. 2009. 'Transforming knowledge: Indigenous knowledge and culture workers on the south coast of New South Wales.' Unpublished Doctoral Dissertation, Canberra: Australian National University.

Rapport, Nigel and Joanna Overing. 20oo. Social and Cultural Anthropology: The Key Concepts. London: Routledge.

Reconciliation Australia. 2010. 'Closing the Gap - Life Expectancy' Factsheet, 14 April. https://www.oxfam.org.au/wp-content/uploads/2012/o1/qa-closingthe-gap-life-expectancy1.pdf

Rudd, Kevin. 2008. 'Apology to Australia’s Indigenous Peoples.' Hansard, House of Representatives, Parliament of Australia, Canberra, 13 February:167-173. 
Sarra, Chris. 2005. 'Strong and smart: reinforcing Aboriginal perceptions of being Aboriginal at Cherbourg State School.' Unpublished Doctoral Dissertation, Perth: Murdoch University.

- 2010. 'Stronger smarter approaches to Indigenous leadership in Australia.' In Closing the Gap in Education? Improving Outcomes in Southern World Societies, edited by Ilana Snyder and John Nieuwenhuysen. Melbourne: Monash University Press. http://books.publishing.monash.edu/apps/bookworm/ view/Closing+the+Gap+in+Education $3 \mathrm{~F} / 182 / \mathrm{xhtml} /$ parto 4 chaptero1.html

Sissons, Jeffrey. 2005. First Peoples: Indigenous Cultures and Their Futures. London: Reaktion Books Ltd.

Wilson, Ronald. 1997. Bringing them home: Report of the national inquiry into the separation of Aboriginal and Torres Strait Islander children from their families. Sydney: Australian Human Rights and Equal Opportunity Commission.

Yamanouchi, Yuriko. 2010. 'Kinship, organisations and 'wannabes': Aboriginal identity negotiation in south western Sydney.' Oceania 8o(2):216-28. 